\title{
Development of Learning Tools Based on Realistic Mathematical Approaches to Improve Mathematical Problem Solving Ability of Students in Class V SD Angkasa 2 Lanud Soewondo Medan
}

\author{
Widda Syafira Abd. Wahab ${ }^{1}$, Sahat Saragih $^{2}$, Siman $^{2}$ \\ ${ }^{1}$ Postgraduate Basic Education Student, Medan State University, Indonesia \\ ${ }^{2}$ Postgraduate Basic Education Lecturer, Medan State University, Indonesia \\ Widda_syafira@yahoo.com
}

\section{Abstract}

This research is motivated by learning tools that do not meet the effectiveness criteria in SD Angkasa 2 Lanud Soewondo Medan. This study aims to describe: 1) the effectiveness of learning tools based on realistic mathematical approaches in improving students' mathematical problem solving abilities; 2) increasing students' mathematical problem solving abilities by using realistic mathematics-based learning tools; 3) the process of student answers in solving problems mathematical problem solving abilities. This study uses a 4-D development model. The subjects in this study were all class V SD Angkasa 2 Lanud Soewondo Medan, with a total of 41 students. The objects in this study are learning tools in the form of lesson plans, textbooks, student activity sheets, and tests of mathematical problem solving abilities. The results showed that: 1) learning devices based on realistic mathematical approaches effectively improve mathematical problem-solving abilities, effectiveness in terms of: a) the percentage of students mastery learning classically which reached 95.24\%; b) achievement of the ideal percentage of student activity time for each category; and c) the average value of the teacher's ability to manage learning is 4.8, including the good category; 2) improvement of students' mathematical problem solving abilities, the average value of achieving mathematical problem solving abilities in the first trial of 45.00 increased to 95.24 in the second trial; 3) the process of students' answers in completing the problem solving ability test questions in try II is better than try I. Then it is recommended that teachers be able to use learning tools based on realistic mathematical approaches as alternative learning.

\section{Keywords}

realistic mathematical approach; mathematical problem solving ability; 4-D development model

\section{Introduction}

Education plays an important role in printing and building a quality generation. Providing quality education is a long-term investment, but to be able to achieve the goals of education is not easy, it is necessary to have a variety of factors that can support these achievements is the teacher. Teachers as agents of change must be able to contribute in creating a generation of quality and high competitiveness. Teachers are required to be more creative and able to find alternatives to solving children's learning problems. Especially in the learning process carried out at school, teachers must be able to integrate and harmonize the activities and creativity of the teacher with the activities and creativity of students in a harmonious and dynamic way, moreover the teacher must be able to awaken the active participation of students in the classroom, and be able to better interpret the activities learning in class, especially in mathematics. 
But in carrying out teaching and learning activities, the teacher is faced with various problems, one of which is the difficulty of students in learning mathematics. These difficulties include difficulties in understanding the concept of problem solving (mathematical problem solving), mathematical reasoning (mathematical reasoning), mathematical connection (mathematical connection), translation of story problems and others. Mathematics is a universal science that underlies modern technology development, has an important role in various disciplines and develops human thought power. Here are some uses of learning mathematics according to Cornelius (Abdurrahman, 2012; 204):

Five reasons for the need to learn mathematics because mathematics is (1) clear and logical thinking suggestions, (2) a means to solve problems of daily life, (3) a means of recognizing patterns of relationships and generalizing experiences, (4) a means to develop creativity, and (5) means to increase awareness of cultural development.

Mathematical learning competencies listed in the 2013 curriculum emphasize to train how to think and reason in drawing conclusions and developing problem solving skills. Mathematical problem solving is very important because trying to find a solution to the problem independently will provide a concrete experience so that the experience can be used in solving similar problems. Problem solving as one of the aspects of higher order thinking skills and a central goal in mathematics learning, as expressed by Ardiah (in Vettleson 2010: 1), in the discipline of mathematics, the use of problem solving skills has been extremely important and is very influential . Problem solving is the foundation of all mathematical and scientific discoveries. "From the above quotation can be interpreted as follows: "In the discipline of mathematics, the use of problem solving skills has a very important influence. Problem solving is the basis of all mathematics and the process of discovering new knowledge. "

The same thing also stated by The National Council of Supervisors of Mathematics (in Hough, 2005: 2) that:

"Problem solving is the process of applying previously acquired knowledge to new and unfamiliar situations. Problem solving startegies involve posing questions, analyzing situations, translating results, illustrating results, drawing diagrams, and using trial and error.

Problem solving is the process of applying previously acquired knowledge to a new situation. Problem solving strategies involve challenging questions, analyzing situations, translating results, describing results, drawing diagrams, and experimenting.

The importance of problem solving skills was also raised by Hudojo (2005: 133)

Problem solving is an essential thing in learning mathematics in schools, due to among others: (1) students become skilled at selecting relevant information, then analyzing it and then examining the results; (2) intellectual satisfaction will arise from within, which is an intrinsic problem; (3) the intellectual potential of students increases; (4) students learn how to make discoveries through the process of making discoveries.

Based on research on low problem-solving abilities conducted by Marzuki (2012) that the initial ability of students in fraction material from 20 students, 15 students scored very less and only 5 people who have enough grades. This shows that the problem solving ability of students is still low. Circumstances like this must be overcome by familiarizing students and training students to answer questions by applying measures of problem solving abilities, this is a provision for students to solve mathematical problems and problems that they find in their daily lives. 
The low problem solving ability can also be seen from the results of initial observations and interviews with the mathematics teacher at SD Angkasa 2 Lanud Soewondo Medan that students have difficulty in solving mathematical problems, the teacher revealed that students are not accustomed to writing down what is known and asked in the problem, even most students are not understand the problem and don't know how to solve it. Observation results also show students are still passive in learning and not giving a positive response to learning when it is ongoing. One of the topics that was felt difficult by students was the matter of stories in the Summification and Reduction Operations material on fractions. The above statement is reinforced by the results of students' answers when giving a test in class V.

Then, based on observations made at SD Angkasa 2 Lanud Soewondo Medan, it was found that the mathematics learning process still adheres to a monotonous way that requires students to only swallow whatever the teacher says. So it is difficult for us to expect students to be individuals who are able to submit their own thoughts, let alone unique ones. They tend to appear as individuals who automatically do the things that are usually done. The Learning Process is still dominated by teachers and does not provide access for students to develop independently through learning activities that prioritize problem solving.

The teacher also still use devices that are ready to be made by other experts, not from the school teachers. So the device used is not in accordance with the abilities of students. Students tend to only memorize a number of material and problem-solving steps that have been done by the teacher or in the textbook. As a result students are passive in learning in the classroom. Learning isolates students from the real life that exists outside of school, is less relevant between what is done with the needs in the work, too concentrated on intellectual development that does not work with individual development as a unified whole and personality. Whereas the development of science and technology today requires students to be educated into open-minded civil society who are always struggling to improve themselves through a number of creative thoughts in the face of various demands that are always increasing and changing.

In improving problem solving skills, efforts should be made. One key is to improve teacher quality, the government has carried out many programs to improve the quality of teachers, but these efforts are in vain if the teacher as an important figure does not improve his own quality. The teacher must also be able to develop effective and attractive learning tools so that students have a positive response to the learning delivered. Creativity in developing learning resources is very important, not because of limited facilities and funds, it is also necessary to develop learning tools that are appropriate to the learning methods and strategies used. For this reason, teachers are required to prepare learning designs such as the development of learning tools.

In resolving these contextual problems students are directed into independent or cooperative learning situations in small groups. The principle in PMR is to encourage students to explore various mathematical ideas and construct knowledge so as to improve students' mathematical solving abilities.

In learning with PMR students must actively construct their own mathematical knowledge. Students are encouraged and given freedom to express their thoughts. As stated by Hasratuddin (2010), one of learning that refers to the learning process that contains constructive, interactive and reflection elements is the learning of realistic mathematics, which in its native Netherlands, is called Realistic Mathematics Education (RME) and has been developing since the 1970s. The philosophy underlying realistic mathematics learning is that mathematics is seen as human activity (Freudhental, 1991; Treffers \& Goffre, 1985; 
Gravemeijer, 1994; Moor, E. 1994; de Lange, 1996). So that mathematics does not have to be given to students in the form of "results", but students must construct their own content of knowledge through interactive contextual problem solving, both informally and formally, so that they find themselves or with the help of adults / teachers, whether their answers are true or false.

The objectives of this study are: 1) To find out the improvement of students' dramatic problem solving abilities at SD Angkasa 2 Lanud Soewondo Medan by developing learning devices based on realistic mathematics approach (PMR), 2) To fulfill effective learning tools based on realistic mathematical approaches to improving problem solving abilities mathematics at SD Angkasa 2 Lanud Soewondo Medan, 3) To find out the most dominant mistakes made by students in solving mathematical problem solving abilities.

\section{Literature Review}

\subsection{Learning Mathematics with a Realistic Mathematical Approach}

The learning model with a realistic approach emphasizes how students discover concepts or procedures in mathematics through the encouragement of contextual problems. In resolving these contextual problems students are directed into independent or cooperative learning situations in small groups. (Suciati (1997: 88) said that one of the characteristics of small group learning (interactive) has a member of 3 to 9. Verschaffel (1997) says that the steps to solve problems are understanding the problem situation, building mathematical models, compiling mathematical models or operations in the elements of known problems, interpretation and evaluation of the results of the work of computational models and communicating results.

Treffers, A and Goffree (1985) say that teaching with a realistic mathematical approach is characterized as follows:

1. Mathematics is seen as a daily human activity so solving problems in daily life (contextual problems) is an essential part.

2. Learning mathematics means working with mathematics.

3. Students are given the opportunity to discover mathematical concepts or procedures under the guidance of the teacher.

4. The teaching and learning process takes place interactively, and students become the focus of all activities in the classroom. This condition changes the authority of the teacher who was originally a facilitator to become a mentor. The teacher must practice this authority by choosing instructional activities to be carried out, carrying out and guiding the discussion, and selecting the contributions made by students (to be discussed classically).

5. Activities undertaken include; explain contextual problems, solve problems and organize teaching materials.

While the situation of students in learning in a realistic approach is as follows:

1. Using contextual problems to be understood mathematically.

2. Formulate problems from situations outside or inside mathematics by finding mathematical models.

3. Develop and use various strategies to solve problems with mathematical concepts or procedures.

4. Checking and interpreting results referring to the initial problem situation.

5. Generalize solutions and strategies for new problem situations.

The teacher is a facilitator, meaning the teacher provides a variety of contextual problems about the material to encourage students to find the concept or procedure contained 
in it, while students reduce the dependence of their activities on the teacher in solving problems. The teacher facilitates the discovery process in problem solving situations with a variety of questions, stimuli, motivations and a little guidance.

The steps of teacher and student activities in realistic mathematics approach activities are: (a) Understanding contextual problems, (b) Resolving contextual problems, (c) Comparing or discussing answers, (d) Concluding.

1) Learning Implementation Plan (RPP)

Learning Implementation Plan (RPP) is a plan that describes the procedure and organization of learning to achieve a basic competency set in the content standards and outlined in the syllabus.

2) Textbooks

Books as a learning tool must provide benefits for teachers, especially students. In the Ministry of National Education (2008: 12) explained that the book is a written material that presents the knowledge of the ideas of the author. Trianto (2013: 227) added, the student book is a guide for students in learning activities that contain subject matter, inquiry activities based on concepts, activities science, information and examples of application in everyday life. He further explained that, the book as a written material that contains a scientific analysis of the results of the curriculum. The substance of the book is the knowledge arranged according to the established curriculum, arranged to facilitate the teacher in learning and students to learn.

3) Student Activity Sheet (LAS)

Trianto (2011: 223) says the Student Activity Sheet (LAS) contains a set of basic activities that must be carried out by students to maximize understanding in an effort to form basic abilities according to indicators of learning achievement that must be taken. Student activity sheet is a worksheet that contains information and instructions / instructions from the teacher to students to work on a learning activity in the form of work, practice or in the form of the application of learning outcomes to achieve a goal.

4) Troubleshooting Ability Test

The students 'problem solving ability test in mathematics is a test used in measuring students' ability to involve thinking skills in order to be able to solve problems. In the process of finding answers that are measured based on 3 problem solving processes as previously explained namely: (1) Creating a mathematical model of a situation related to real world problems; (2) Selecting a problem-solving strategy that is appropriate for the problem of the mathematical model; and (3) Explain the answers and check the truth. This problem solving ability test is a written test in the form of a description. The test given has the aim to see the extent of students' mathematical problem solving abilities.

\section{Research Methods}

The subjects in this study were all class V SD Angkasa 2 Lanud Soewondo Medan, with a total of 41 students. The objects in this study are learning tools in the form of lesson plans, textbooks, student activity sheets, and tests of mathematical problem solving abilities.

\section{Research Results and Discussion}

Data obtained from the results of the posttest mathematical problem-solving ability of students in the first and second trials were analyzed to determine the improvement in 
students' mathematical problem solving abilities by comparing the average student scores resulting from the first and second trials. Description of increasing students' mathematical problem solving abilities by using learning tools based on realistic mathematical approaches in trials I and II.

Table 1. Description of Results of Mathematical Problem Solving Ability

Furthermore, a description of improving students 'mathematical problem solving abilities by using learning tools based on realistic mathematical approaches in trials I and II for each indicator of students' mathematical problem solving abilities can be seen in the following table:

Table 2. Average Students Mathematical Problem Solving Ability for Each Indicator

\begin{tabular}{lccc}
\hline \multirow{2}{*}{$\begin{array}{l}\text { Indicators of Mathematical Problem } \\
\text { Solving Capabilities }\end{array}$} & \multicolumn{2}{c}{ Average } & \multirow{2}{*}{$\begin{array}{c}\text { Average } \\
\text { increase }\end{array}$} \\
\cline { 2 - 3 } & Trial I & Trial II & \\
\hline $\begin{array}{l}\text { Write down what is known and asked in } \\
\text { the problem }\end{array}$ & 2,65 & 3,00 & 0,35 \\
\hline $\begin{array}{l}\text { Write down the model used in solving } \\
\text { problems }\end{array}$ & 2,65 & 2,92 & 0,27 \\
\hline $\begin{array}{l}\text { Perform calculations according to plans } \\
\text { that have been made }\end{array}$ & 3,19 & 3,24 & 0,05 \\
\hline $\begin{array}{l}\text { Perform one of the following activities: } \\
\text { 1. Check whether the answers } \\
\text { obtained are correct }\end{array}$ & 0,89 & 2,17 & 1,28 \\
$\quad$ 2. Check answers in different ways & & & \\
\hline
\end{tabular}

\subsection{Effectiveness of Learning Tools Based on Realistic Mathematical Approaches}

In determining effectiveness seen from three aspects, namely the classical learning completeness of students, the achievement of learning objectives, and the achievement of ideal time for student activities. The following will be presented a discussion for each indicator in measuring or seeing the effectiveness of learning tools based on realistic mathematical approaches.

\section{a. Completeness of Student Learning Classically}

This criterion is fulfilled if more or equal to $85 \%$ of students are stated to have the ability to solve mathematical problems with a score of at least 75 (KKM complete category). In this study, the second trial phase met the classical completeness criteria. So it can be concluded that the learning device developed has met the effective criteria.

The results of the study above indicate that the mastery of student learning classically

\begin{tabular}{lcc}
\hline Information & $\begin{array}{c}\text { Posttest Mathematical } \\
\text { Problem Solving Ability Test I }\end{array}$ & $\begin{array}{c}\text { Posttest Mathematical Problem } \\
\text { Solving Ability Test II }\end{array}$ \\
\hline Highest score & 92 & 98 \\
\hline Lowest score & 50 & 58 \\
\hline Average & 72,79 & 87,09 \\
\hline $\begin{array}{l}\text { by using learning tools that are developed meets the effectiveness criteria. This is because } \\
\text { learning tools based on the Realistic Mathematical Approach (PMR) are developed in }\end{array}$
\end{tabular}


accordance with the conditions of the student's learning environment and refer to realistic problems. In line with Vygotsky's view (Trianto, 2011: 39), namely the existence of assistance by teachers in the early stages of learning and reducing (Scaffolding) as they complete their assignments. The more active students handle their learning assignments, the more effective learning will be carried out and the impact on classical student completeness.

The above explanation is in line with Rahman's research (2016) to produce learning tools based on a realistic mathematical approach in improving effective mathematical problem solving, with classical completeness of mathematical problem solving abilities that have been fulfilled.

This classical learning completeness is supported by the results of research by Makonye (2014: 653) which states that "The use of different representations and models; verbal, visual, graphical and symbolic on the realistic mathematics education approach providing that guides the discussion ". The meaning of the statement is the use of various representations and models, verbal, visual, graphic and symbolic in a realistic mathematics education approach providing a framework that guides the discussion in a better direction.

In addition, the results of Webb's research (2011: 47) which also states that:

The utility of RME in informing the design of a more student-centered mathematics classroom. U.S. College suggest this approach may benefit students who have been underserved by traditional approaches to mathematics instruction

The meaning of the statement is the use of realistic mathematics education in informing the design of student-centered mathematics classes. Colleges in the United States suggest this approach can be beneficial for students who have been served by traditional approaches to mathematics instruction.

Other relevant research results are the results of research Nursanti, Rochsantiningsih, Joyoatmojo and Budiyono (2016: 323) which concluded that:

Cooperative learning models that collaborate inquiry-based realistic mathematics education approaches as an effort to improve students' characters. The implantation of character values in mathematics is integrated in Syllabus and Lesson Plan, and then, it is implemented in Mathematics education ".

The statement above implies that the character of students increases with cooperative learning models that are collaborated with inquiry-based realistic mathematical approaches. Implantation of character values in mathematics is integrated in the syllabus and lesson plans and later, this is applied in mathematics education.

The development of learning tools based on a valid and effective realistic mathematics approach can improve students' mathematical problem solving abilities. This can be seen from the mastery learning that has met the percentage of mastery learning classically, the achievement of the ideal time in the first try and the second trial meets the ideal criteria, and student responses show very positive response results.

\section{b. Achievement of the Ideal Student Time Percentage}

Based on the analysis of data on student activities in the first and second field trials it was found that the five categories of students had fulfilled the ideal ideal time criteria. It can be concluded that the activities of students using teaching materials developed have met the effective criteria.

It is natural that the achievement of the ideal time by using learning tools based on a realistic mathematics approach meets the effectiveness criteria. This is because by using a realistic mathematical approach during the learning process, students are involved in their 
own investigations, allowing them to interpret and explain real-world phenomena and build understanding of these phenomena independently. The role of students is very large in the realistic mathematics approach so that teachers no longer play the role of the main parties involved in the learning process.

This is in line with the theory of constructivism from Piaget (Sugiyono, 2009: 125), in which the theory emphasizes the importance of students 'activities to actively build their own knowledge, such as students' activities in processing materials, working on problems, making conclusions, and formulating a formula with own words. In line with that according to Bruner (Suwarsono, 2002: 25), learning is an active process that allows humans to discover new things beyond (exceeding) the information provided to him. Thus, student activities in the learning process need to be considered as effectively as possible in the learning process.

Achieving this ideal time percentage is strengthened by the results of Ekowati, Ardi, Dervish, Ua, Tahmir and Irawan (2015: 42) research findings which states that:

With a realistic approach to mathematic teachers, it can change the habit from the original roel in which the teacher is considered as a speaker or the giver of information which is active and creative in enhancing student leatning activities. In contrast, students who had previously studied in passive attitude and wait for the teacher's explanation will become active and creative students. The above statement implies that with a realistic approach to mathematics teachers, it can change the habits of the original role where the teacher is considered as an active and creative facilitator and mediator in increasing student learning activities. Conversely, students who have previously learned to be passive and wait for the teacher's explanation will become active and creative students.

Coupled with the results of research Sinaga (2007) which shows the level of student activity has met the ideal time tolerance limit based on effective criteria. Based on the above opinion it can be concluded that, the ideal time achievement of activities shows the use of learning tools that are developed to meet the effectiveness criteria.

\section{c. Teacher's Ability to Manage Learning}

Based on the results of data analysis the teacher's ability to manage learning at each friend reached good criteria. Every teacher is required to have the ability to manage classrooms in order to achieve a conducive classroom atmosphere from the beginning to the end of learning. The inability of teachers to manage learning causes the goals to be achieved in learning are not optimal.

According to De Lange (Fauzan, 2002: 44) states there are five characteristics in conducting PMR-based learning: (1) The use of real-life context, (2) the use of use models. (3) Student's free production; (4) interaction, (5) intertwining. In the PMR learning process, teachers are required to have the ability to manage learning tools by using contextual problems, using several models, using student contributions, student interaction, and the interrelationships between learner topics.

The ability of teachers to manage learning is strengthened by the research results of Sembiring, Hadi and Dolk (2008: 927) which show that "The ability of teachers to manage learning with RME in both categories and the teachers were actively involved in developing the materilas". The statement means that the teacher's ability to manage learning with RME is in the good category and the teachers are actively involved in developing the material.

The results of this study were also strengthened by Wasriono, Syahputra and Surya (2015) which showed that the ability of teachers to manage learning on mathematical 
learning tools in good criteria. The teacher's ability to manage learning shows the use of learning tools developed that meet the effectiveness criteria. Based on the results of the above research exposure, it can be concluded that the ability of teachers to manage learning shows the use of learning tools based on realistic mathematical approaches that are developed to meet the effectiveness criteria.

\subsection{Improvement of Students Mathematical Problem Solving Ability by Using Learning Tools Based on Realistic Mathematical Approaches}

Based on the results of the analysis of the improvement of students' problem solving abilities in trials I and II showed that the average problem solving ability of students in the results of the first test posttest was 72.79 increased to 87.09 in the second trial. Thus, an increase in the average value of students' mathematical problem solving abilities by 14.3. Furthermore, an increase in each indicator of students 'mathematical problem solving ability is an increase in students' mathematical problem solving ability on the indicator

Through the application of good learning tools, approaches and appropriate learning media, students must be able to construct their own knowledge and skills that are needed. Mathematical problems refer to the facts that exist in the daily lives of students and use media that are often seen, often even used by students, they will create their own interests of students in mathematics. Because the problems given have to do with what they experience in everyday life.

In line with this, Trianto (2011: 105) PMR emphasizes higher level thinking, transfer of knowledge across disciplines, as well as the collection, analysis and consistency of information and data from various sources and views. Knowledge influences the concept of the learning process, because learning is not merely memorizing but constructing knowledge through experience. According to Piaget (Trianto, 2011: 14), cognitive development of students at the age of 7-11 years is a concrete operational stage. The results of the analysis of the age of students of SD Angkasa 2 Lanud Soewondo Medan average age 10-11 years. Therefore, it is very appropriate if learning mathematics begins with concrete or tangible objects that are close to their lives, so that it is expected to help improve students' mathematical abilities. Increased ability based on a realistic mathematical approach is strengthened by the results of research Wardono (2014: 362) which states that:

The learning devices of innovative realist learning with character education and PISA assessment which have been developed could be categorized as valid, practical, and effective to improve the junior high school students mathematics problem solving literacy. The result also suggests that the learning quality can be categorized as good and the students character improves better.

The meaning of the above statement is a learning tool from innovative realistic learning with character education and the assessment of PISA that has been developed can be categorized as valid, practical, and effective to improve the literacy of mathematics problem solving for junior high school students. The results also show that the quality of learning can be categorized as good and the character of students increases better.

Students' problem-solving abilities were significantly better by using learning tools for realistic mathematical approaches that were tested with valid and effective criteria. Other research results that strengthen the results of this study are the Primary, Minarni and Saragih research (2017: 18) states that: "There is an increased ability to understand mathematical concepts after using the learning devices based on realistic mathematical approaches integrated context Malay Deli culture". The statement implies there is an increase in the 
ability to understand mathematical approaches based on realistic mathematical approaches based on the context of Deli Malay Culture.

Besides that, based on the results of tests of mathematical problem-solving abilities that were carried out, it was found that students' weaknesses in solving one aspect of the indicator of problem-solving ability tests were students having difficulty checking the answers to the questions. These findings are in line with research conducted by Yuliani and Saragih (2015) in their research that students have not really been able to recognize and solve the problems given. Thus it was concluded that the students' weaknesses in problem-solving abilities were found in the indicator of checking answers correctly and clearly.

\subsection{Student Answer Errors in Solving Mathematical Problem Solving Abilities}

The process of student answers is seen based on indicators of each student's mathematical problem solving ability. From the results of the analysis of the answer process carried out, the process of student answers in the second trial obtained more "good" assessment criteria. The process of student answers in try II is more structured, systematic, varied, and in accordance with indicators of mathematical problem solving ability when compared to the process of student answers in try I.

This is because the learning process by using realistic-based learning tools, students are required to think more exploratively than just mechanical and procedural thinking. In addition, students are trained to solve problems that are often experienced by students, by providing problems that are often experienced by students, the mindset of students is not only limited to textbooks, but they can solve problems in their own way and the steps of solving that they consider right.

Markaban (2006: 15) revealed that accustoming students in problem solving activities can be expected to improve students' abilities in working on math problems, because students are involved in thinking mathematics when manipulating, experimenting, solving problems. This is in line with the theory of Constructivism from Piaget (Trianto, 2011: 39), in which the theory emphasizes the importance of the activities of students to actively build or construct their own knowledge. So that it has an impact on the results of the posttest of the ability to understand concepts and think critically mathematically, where most students' answers are systemic, structured, varied and in accordance with indicators of understanding the ability of mathematical concepts and critical thinking. Unlike ordinary learning, students are only required to answer the questions correctly as exemplified by the teacher.

This is in line with the results of research by Raudatull et al (2015) stating that: an increase in students' problem solving abilities using a realistic mathematical approach is higher than students who obtain conventional learning, the problem solving process answers students whose learning using a realistic mathematics approach is better compared to conventional learning. Furthermore Dickinson et al (2010) conclude "this is a futher evidence that pupils are taught an RME based curriculum is more able to make sense of their mathematics, bath in achieving answers and in reasoning why thet feel is correct". This states that students who are taught using the RME-based curriculum can make students better mathematical abilities in obtaining answers and in giving conclusions from the answers they get.

So it can be concluded that the process of answering students who get answers with a realistic mathematical approach is better at solving problems problem solving abilities. 


\section{Conclusion}

Based on the results of the analysis of the discussion in this study, several conclusions are made as follows:

1. Learning devices based on realistic mathematical approaches in improving mathematical problem solving abilities have been effective for use in learning, which includes (1) the achievement of classical students' completeness of learning which reaches $95.24 \%$; (2) the achievement of the ideal percentage of student activity time for each category; and (3) students' responses to the components of the learning tools and learning activities developed are positive. .

2. There is an increase in students' mathematical problem solving abilities. Improved students' mathematical problem solving skills seen from the average value of problem solving abilities. Based on the results of research students' mathematical problem-solving ability has increased, this can be seen from the percentage of classical completeness of students in the first test of 45.00 then increased in the second posttest to 95.24. This shows an increase of 50.24 from posttest I to posttest II.

3. Student answer errors in completing the problem questions of the most dominant problem solving ability of students in trials I and II are mistakes in re-checking answers. However, the answers of students in the second trial were more structured, systematic, varied, and in accordance with indicators of mathematical problem-solving ability when compared with the students' answer processes in the first trial.

\section{References}

Abdurrahman, M. 2003. Pendidikan Bagi Anak Berkesulitan Belajar. Jakarta: Rineka Cipta.

Diba, (2009), Pengembangan Materi Pembelajaran Bilangan Berdasarkan Pendidikan Matematika Realistik Untuk Siswa kelas V Sekolah Dasar. Palembang

Dickinson, P., Eade, F., Gough, S., Hough, S. 2010. Using Realistic Mathematics Education with Low to Middle Attaining Pupils Secondary Schools, Proceedings of The British Congress For Mathematics Education.

Dickinson, P., Eade, F., Gough, S., Hough, S. 2010. Using Realistic Mathematics Education with Low to Middle Attaining Pupils Secondary Schools, Proceedings of The British Congress For Mathematics Education.

Fauzan,A. 2002. Applying Realistic Mathematics Education (RME) in Teaching Geometry in Indonesian Primary Schools. Thesis University of Twente, Enschede.

Gravemeijer, K.P.E (1994). Developing Realistic, Mathematics Education. Utrecht, the Netherlands: CD- $\beta$ Press, Freudenthal Institute

Hadi, S. 2005. Pendidikan Matematika Realistik. Banjarmasin: Tulip

Hasratuddin. (2010). Meningkatkan Kemampuan Berpikir Kritis Siswa SMP melalui Pendekatan Matematika Realistik. Surabaya: Program Pascasarjana Studi Pendidikan Matematika.

Hasratuddin. (2010). Pembelajaran Matematika Dengan Pendekatan Realistik. Jurnal Pendidikan Matematika PARADIKMA, 3(1): 19-30

Hasratuddin. (2015). Mengapa Harus belajar matematika?. Medan:Penerbit Perdana Publishing. 
Hudojo, H. (2005) Pengembangan Kurikulum dan Pembelajaran Matematika. Malang: Penerbit Universitas Malang

Makonye, J. P. 2014. Teaching Functions Using a Realistic Mathematics Education Approach: A Theoretical Perspective. Internasional Journal Education and Science, vol, 7, no. 3, pp. 653-652. (Online), (http://krepubhlishers.com/02-Journals/IJES/IJES-07-0000-14-web/IJES-07-3-000-14-ABST-PDF/IJES-7-3-653-14-489-Makonye-J-P/IJES7-3-653-14-489-Makonye-J-P-Tx[27].pdf, diakses 9 juli 2018).

Markaban,2006. Model Pembelajaran Matematika dengan Pendekatan Penemuan Terbimbing. Yogyakarta: Departemen Pendidikan Nasional.

Marzuki. 2012. Perbedaan Kemampuan Pemecahan Masalah dan Komunikasi Antara siswa yang diberi Pembelajaran Berbasis Masalah dengan Pembelajaran Langsung. Tesis tidak diterbitkan, Medan : Program Pascasarjana UNIMED.

Nursanti, Y. B., D. Rochsantiningsih, S. Joyoatmojo dan Budiyono. 2016..Mathematiics Education Model in Indonesia Through Inquiry-Based Realistic Mathematics Education Approachto Improve Character. Internationa Journal of Education and Research, vol.,4, no.9, pp. 323-332. (online), (http://www.ijern.com/journal/2016/September2016/28.pdf, diakses 20 Maret2018).

Penalaran Matematika Siswa SMP Kelas VIII. PYTHAGORAS: Jurnal Pendidikan Matematika Volume 11 - Nomor 2, Desember 2016, (169-181), (Online), (http://journal.uny.ac.id/index.php/pythagoras, diakses 18 September 2019)

Pratama, S., A. Minarni dan S. Saragih. 2017. Development of Learning Devices Based on Realistic Approach of Understand Mathematical Concepts and Students' SelfRegulated Learning At SMP Negeri 5 Medan. International Organization of Scientific Research Journal of Mathematics, vol. 13, no. 6, pp. 18-29. (Online), (http://www.iosrjournals.org/iosr-jm/papers/Vol13-issue6/Version-2/D1306021829. Pdf, diakses 20 Agustus 2018)

Sembiring, R. K., S. Hadi dan M.Dolk. (2008) reforming mathematics learning in indonesian classrooms through RME. ZDM-The international journal on mathematics education, vol. 40, no.6, pp. 927-939. (online), (http://link.spinger.com/article/10.1007/s11858008-0125-9, diakses 20 januari 2018).

Sinaga, Afni. (2016). Pengembangan Tes Kemampuan Pemecahan Masalah dan

Trianto. 2009. Mendesain Model Pembelajaran Inovatif Progresif. Jakarta: Kencana Prenada Group.

Wardono. 2014. The Realistic Learning Model With Character Education and PISA Assesment to Improve Mathematics Literacy. International Journal of Education and Research, vol. 2, no.7, pp. 361-372. (Online), (http://www.ijern.com/journal/july2014/30.pdf, diakses 20 Februari 2018).

Widjaja, Y. \& Heck, A. 2003. How A Realistic Mathematics Education Approach and Microcomputer-Based Laboratory Worked in Lessons on Graphing at an Indonesian Junior High School. Journal of Science and Mathematics Education in Southest Asia. 26(2): 1-51.

Tim Visi Yustisia, 2015, Panduan Resmi Hak Cipta, Visi Media, Jakarta. 